\title{
The Pursuit and Innovation of Formal Beauty in Modern Art
}

\author{
Li Minfang ${ }^{1,}$, Li Minyan ${ }^{1, b}$ \\ ${ }^{1}$ Jiangxi Science \& Technology Normal University, Nanchang, Jiangxi, 330013, China \\ a63910546@qq.com, ${ }^{b} 724390219 @ q q . c o m$
}

Keywords: Modern art; ceramics; formal beauty; innovation; cultural connotation

\begin{abstract}
In the modern art, ceramic art forms are very rich. From the development characteristics of ceramic technology point of view, it implements the traditional culture and decorative arts of mutual integration, can constitute a unique visual effects. With the expression of modern art ceramic form, the majority of design workers to deepen the ceramic art form of the United States to explore. Innovation, breaking the development of traditional art malpractice, build personalized, novel aesthetic image. In this paper, for the modern art of ceramics, the pursuit of formal beauty and innovative content to explore.
\end{abstract}

\section{Introduction}

With the development of the times, the development of modern ceramic art in China has reached a certain stage. Modern ceramic art is the accumulation of traditional Chinese culture, but also an important category in artistic creation. The advent of ceramics derived from ceramic decoration, ceramic home, ceramic utensils, and many other values, different forms of ceramic art so that the richer connotation, but also more time value and artistic value. From the development of ceramic technology point of view, whether it is tire decoration, glaze decoration, underglaze color, etc., can constitute a unique artistic expression.

\section{Formal Beauty Value in Modern Art}

The shaping of ceramic craft refers to the artistic treatment on the surface of ceramic utensils, which embodies the unique charm of ceramics and realize the unity of economic value, artistic value and artistic accomplishment. The aesthetic value of ceramic technology is both rational and extended to the sensibility, which is the direct expression of human's thoughts and feelings and labor wisdom. With the improvement of pottery, the development of pottery from the traditional form of production, pay more attention to the structure and composition, so that ceramic art and people's aesthetic needs and create value of mutual integration.

Fundamentally speaking, Chinese ceramic art has become the representative of national culture with its unique oriental charm. Ceramic art performance characteristics need to combine the shape of containers, decorative drawings, so that people feel the art of the image of the United States and the United States. With the help of modern ceramic forms of art, to achieve and modern decoration of the integration, through constant pursuit and innovation to break the traditional art of abuse.

\section{The Development History of Modern Art Ceramic}

In China, pottery manufacturing process can be traced back to the era before 4500 years ago. The development of ceramic art has gone through a long history of development. This development factor deeply affected the development of modern ceramics. So that modern ceramics in the specific classification includes both the rigid technical indicators, including the traditional regional division. From the origin of development, the Yangshao culture represented by painted pottery opened the door of pottery art. The development of the Han Dynasty, the artists began to try to give up in the creation of jade and metal, in the firing techniques and design forms of new breakthroughs, developed a more compact glazed pottery. After the Six Dynasties, the development of the Tang Dynasty, the ceramic industry in the Song Dynasty has been further improved. Formed to Jun, Ru, Guan, Ge, as the 
representative of the ceramic industry distribution. Ming and Qing Dynasties, Kangxi, Qianlong, Yongzheng shaping known as the Qing Dynasty under the glorious period, in particular, Jingdezhen ceramic industry began to flourish. From the history of the development of ceramic art point of view, the development of modern art ceramic personality is not "air loft", but from history, for the modern form of ceramic art.

\section{The Pursuit and Innovation of Formal Beauty in Modern Art}

The development of pottery is the representative of the handicraft industry from the Paleolithic to the Neolithic Age. With the development of modern ceramic art, in the modern art ceramics, the creators in the process of expression on the way through the multi-improvement, so that the form of ceramic art showing the beauty.

(1) mildly smooth, the pursuit of modern art in the United States and the line of ceramics

Formal beauty has always been a common concern in Chinese and Western artistic philosophy. In the creation of modern art ceramics, both in the appreciation of ceramic art or ceramic aesthetic ability, are playing an important role. For the modern art of ceramics, the unique shape feel, smooth lines is to appreciate the shape of the ceramic art for the visual requirements.

From the visual perception, the modern art pottery is different from the traditional ceramics, its shape contours do not rigidly adhere to the law-abiding, but from the pure straight lines developed, began along the curve shape, irregular, personalized change development. Compared with the traditional ceramic art, modern art ceramics pay attention to the shape of the beautiful, profound connotations and rich heritage. Is the ceramic creator according to their emotions extracted from the ideological and emotional.

From primitive society painted pottery to the Ming and Qing Dynasties era of porcelain, no matter what kind of vessel, the shape of the containers are beautiful, full flavor, smooth lines of ceramic shape. Ceramic utensils need to rely on the shape of the form, body, rhythm and rhythm, can give a profound artistic experience.

For example, in the "matter of fact" in the exhibition of contemporary ceramic ceramics in Israel, the broad masses of ceramic art lovers have jointly interpreted the function, production and thinking of modern ceramic art. In the modern art ceramic works "hope and despair", the author of the use of Mielio resin for sliding porcelain creation, the vessel line design rounded smooth, full sense of extension. The work is a set of three pieces of utensils, in the utensils lines, the design of the form of construction and interpretation. With the help of the unique beauty of the lines, in the modern art of ceramic production methods, materials, industry, technical aspects of the show hope and despair intertwined thoughts and feelings.

(2) in different forms, grasp the physical beauty of modern ceramic art

In the modern ceramic design, according to the selected raw materials, techniques and other new design differences, can bring ceramic art works of major development and change. For example, the Shang Dynasty white porcelain production methods in the experience of modern ceramic artists after the improvement, the use of less impurities in the clay pottery, the white pottery fineness more clean and flawless. As a result, in the shape of some pure, simple modern ceramic design, the material more in line with the designer's original intention, in the carving techniques are more suitable for moire, dragon and phoenix and other classic fine patterns. To achieve the characterization, hollow, stacked paste and other forms of artistic ceramics. In the shape of the overall vessel portrayed, decorative composition line, to create a rich and varied ceramic art form.

For example, some ceramic art enthusiasts are very fond of traditional art, in the shape of the well-known generals on behalf of the Yuan Dynasty, Yuan Dynasty Longquan kiln wine bottle, the shape of the external vessel design and change. In the bottle to simplify the place, try to use a variety of methods of ceramic art innovation. In the shoulder of the radius of the place to stretch, so as to form the ups and downs, the atmosphere seamless physical art, ceramic art can make the form of a more diversified form.

(3) Glaze Smart, to promote the glaze of ceramic art forms the United States 
Since the Ming and Qing Dynasties, the glaze of ceramic art embodies the wisdom of ceramic art workers. Ceramic glaze with temperature, technology, etc. echo each other. In the history of IDE development in the accumulation of light, color, transparent, aesthetic characteristics of clean. Among the four famous kiln "Ru", the different glaze can give a different feel. Tea at the end of stability key depression, azure clear clear, are kiln color magnificent as the horizon of glow, kiln glaze thick as white jade. Therefore, in the modern art of ceramics, ceramic designers need to develop a scientific formula of ceramic glaze, and further innovation in visual color.

For example, "kiln change" is an important art of modern art ceramic glaze techniques. The appearance of the kiln can show a wonderful container texture. Some like cheetah markings, some like the peacock feathers, some like water texture, some like the sky's afterglow. Different glaze recipes can give people a different feel, so that the decorative form of contemporary ceramic art containers more flexible. Ceramic designers to more their own actual situation, and further innovation in ceramic technology, in the glaze gold, glaze accumulation, etc., to burn, to show a unique artistic beauty.

(4) silk Yun deep, enhance the contemporary art of ceramic art thought

For a good work of art, "thought" needs to run through the connotation of the work. Ceramic art as a national heritage, with a delicate moist, bright jade development characteristics, it should be in the design, firing process, and further inherited the traditional ceramic sculpture skills, and should not forget the use of modern aesthetic concepts, in the works To instill a deep cultural heritage, so that contemporary porcelain art more vibrant and dynamic.

For example, in the ceramic exhibition room of Dehua Hengyu Co., Ltd., there is a contemporary ceramic art "Aromatic Fragrance" produced by Zhou Jintian, a ceramic master. This is a portrait of porcelain, mainly in ladies' Made on the Dehua porcelain clay as raw materials, so that the fineness of the works Wenrun, showing the ladies were "full"

Of the body image. In the works to reflect the modern society to thin women for the United States and blindly lose weight health problems, echoing the modern lady to be rational to lose weight, in the ceramic art into a modern culture of art and ideas. Ceramic art lovers to reflect the social thinking, and the traditional Chinese culture in the ceramic design integration, and guide people to pay attention to the modern art of ceramic design new ideas and new thinking, to produce a modern aesthetic, able to spread to the rest of the world, Promote the excellent ceramic art of oriental culture works.

\section{Summary}

In summary, in the modern art of ceramics, the pursuit of formal beauty exists in the development of the whole. To this end, the majority of ceramic art and design workers should be based on the development of ceramic art on the structure, to further design good works, pay more attention to culture and skills, tradition and innovation of mutual integration. So that ceramic works of art can get more attention, and continuously enhance the modern art of ceramics in the international appeal, influence.

This paper is one of the achievements of Jiangxi Science and Technology Normal University in 2014, the research and development of ceramic toys in Jiangxi tourism market (No. 2014XJYB010).

\section{References}

[1] Li Yanzu, Wen Yun, "The Beauty of Fire" - Ceramic Artist Ning Gang and His Works [J] .Arts Contest, 2011 (09).

[2] Zhou Tong, Xu Liang. On the artistic concept of modern art under the influence of ceramic art [J]. Journal of Nanjing Art Institute (Fine Arts and Design), 2012.

[3]. Xi Mu. Should pay full attention to the construction of ceramic kiln in the role of aesthetic culture [J]. Collection, 2014 (11). 